\title{
Natural ventilation in insect screened single span greenhouses under warm weather
}

\author{
Palitha WEERAKKODY ${ }^{1 *}$, Sanath AMARATHUNGA ${ }^{2}$, Sarath \\ WARNAKULASOORIYA ${ }^{1}$ and Sanjeeva HERATH ${ }^{1}$ \\ ${ }^{1}$ Department of Crop Science, Faculty of Agriculture, University of Peradeniya, Peradeniya 20400, Sri Lanka. \\ ${ }^{2}$ Department of Agric. Engineering, Faculty of Agriculture, University of Peradeniya, Peradeniya 20400, \\ Sri Lanka. \\ *Corresponding author, E-mail: palithaw@pdn.ac.lk
}

\begin{abstract}
The ventilation rates of different types of ridge vents in combination with insect-screened side vents were assessed in single greenhouses in terms of the difference in temperature and humidity inside and outside under tropical conditions. The A-frame (slanted roof) was comparatively advantageous over the conventional arch frame (curved roof) for keeping daytime temperature lower in single span greenhouse with insect-screened side vents (mesh size: 1 by $1 \mathrm{~mm}$ ) and without roof vents. The inclusion of ridge vents further reduced the internal temperature and relative humidity $(\mathrm{RH})$ in the A-frame greenhouse during the daytime. The opening area of the ridge vent within the range between $9.3 \%$ and $14 \%$ (of the floor area) did not significantly change the ventilation based internal temperature and RH when operated under low wind speeds $\left(0.5 \pm 0.5 \mathrm{~m} \mathrm{~s}^{-1}\right)$. Meanwhile the effect of ridge orientation, with respect to wind direction, on greenhouse ventilation was not obvious in terms of temperature or RH under inconsistent wind directions and low wind speeds. Greenhouse ventilation positively responded to low winds $\left(0.25 \mathrm{~m} \mathrm{~s}^{-1}\right)$ by reducing internal temperature as well as RH. However, the response to a further increase in wind speed from 0.25 to $0.5 \mathrm{~m} \mathrm{~s}^{-1}$ was not significant. Based on climate control characteristics an A-frame single-span greenhouse design with double sided alternate ridge vents and insect-screened side vents could be appropriate for tropical climates under low wind speeds and inconsistent wind directions as a cost effective and user-friendly greenhouse design. Particularly, it is highly applicable for the small-scale controlled environment vegetable production in mid and low elevations in the wet zone of Sri Lanka.

(C) 2009 International Formulae Group. All rights reserved.
\end{abstract}

Keywords: Alternate ridge vent, curved roof, continuous ridge vent, ridge orientation, wind effect.

\section{INTRODUCTION}

Increasing crop productivity is the best approach to increase the world food supply in this century. The tropical regions with cheap and yet unexplored resources are the center of attraction in this context. However, unfavorable weather bound constraints have minimized this possibility in the open field. For example, $22 \%$ of field crop, $55 \%$ of vegetable and $35 \%$ of fruit yields are lost due to bad weather in Sri Lanka. Therefore, protected agriculture can provide alternative economic opportunities in crop production to 
feed the hungry world (Jensen and Malter, 1995; Central Bank Report, 2006).

Plastic film greenhouses used in Controlled Environment Agriculture (CEA) in the tropics entrap radiation during the daytime leading to temperature hikes to levels that are undesirable for plant growth. Even though various cooling methods are practiced, they are not able to reduce the temperature sufficiently under hot weather conditions or at low altitudes. As a result, most greenhouse production is confined to regions with high elevations, having cool climates. The crop yields and quality of produce are not satisfactory because of undesirably high temperatures in common curved type film plastic greenhouses in Sri Lanka, especially at low elevations (Weerakkody et al., 2002; Nirangen et al., 2005).

Ventilation, shading and evaporative cooling are some of the techniques that can be used for greenhouse cooling. Natural ventilation through screen-covered fixed top vents (covering $10 \%$ of the roof surface) and screen-covered side vents (extending to the gutters) are most commonly practiced in Sri Lanka, considering the cost factor. The main drawback of this type of vents is the low degree of internal environment control due to inadequate wind-driven ventilation, particularly under less windy periods at low and mid elevations (up to $1000 \mathrm{~m}$ above sea level) and in farmer fields with tall vegetation (reducing the impact of winds). Covering of vents with insect screens further limits the air-flow rates (Fatnassi et al., 2002). Under warm weather, at least $30 \%$ ventilation area (with respect to floor area) should be provided for proper ventilation under hot still conditions (Hanan, 1998; Nelson, 1998). According to earlier work on type, size and orientation of vents, combined roof and side vents oriented in both windward and leeward directions were found to reduce the greenhouse temperature maximally (Short and Lee, 2002; Kalsoulas et el., 2006; Teitel et al., 2006).

Based on these factors, adjustable ridge vents (without insect screens), with different opening angles (areas of opening) and ridge orientations (windward and leeward) were tested as an alternative for screen-covered fixed top vents in single span tropical greenhouses (with insect screened side vents) under low wind speeds and variable wind directions.

\section{MATERIALS AND METHODS}

The experimental greenhouse designs were established in Kandy, in the central highlands of the country $\left(7^{\circ} \mathrm{N}\right.$ latitude and 750 $\mathrm{m}$ above sea level) of Sri Lanka. The mean daytime temperature in the center of the country ranges from 22.5 to $25{ }^{\circ} \mathrm{C}$ and the mean annual rainfall ranges from 2000 to $2500 \mathrm{~mm}$. A mean maximum temperature of $33{ }^{\circ} \mathrm{C}$ and a mean minimum temperature of 22 ${ }^{\circ} \mathrm{C}$ were reported during the experimental period (April to December, 2003). The experimental site represented average conditions for production greenhouses at low and mid elevations in Sri Lanka, especially with respect to wind speed (mean daily wind speeds of less than $1 \mathrm{~m} \mathrm{~s}^{-1}$ ).

As shown in Fig. 1, three A-frame (gable frame or slanted roof) greenhouses, having the same dimensions and with alternate double sided ridge vents (a), with a continuous single-sided (leeward) ridge vent (b) and without ridge vents (c) were primarily used for this experiment. An arch frame (curved roof) greenhouse (without ridge vents) was used for comparison of the roof shape. All these greenhouses were covered with a single layer of UV-protected clear polythene film at the top and at gable ends and with UV-protected insect screen (mesh size: 1 by $1 \mathrm{~mm}$ ) at the ridge side. Ridge vents were not screened while screens in the ridge sides were used as additional air inlets. The dimensions of each greenhouse were 6.1 by $15.2 \mathrm{~m}\left(93 \mathrm{~m}^{2}\right)$, with gutter and ridge heights of $2.4 \mathrm{~m}$ and $4.5 \mathrm{~m}$, respectively. The gutter height of the curved roof greenhouse (d) was adjusted to $2.1 \mathrm{~m}$ in order to keep the internal air volume similar to the A-frame greenhouses. In greenhouses (a) and (b) the 
opening area of the top (ridge) vent was $17.5 \%$ of the floor area while it was $30 \%$ for the insect screened side vent. At a given wind speed, "opening area" is proportional to the ventilation rate. The opening angle of the ventilation windows was adjustable so that the opening area of the ridge openings could be adjusted. At the maximum opening angle of $24^{\circ}$ (from the horizontal plane), the opening area was $14 \%$ of the floor area, while at $2 / 3$ and $1 / 3$ openings, it was $9.3 \%$ and $4.7 \%$, respectively. Besides, the vent windows in each vent were designed $0.8 \mathrm{~m}^{2}$ larger than the roof opening area for proper sealing against entry of air and rain splash when closed. A lever system was used to adjust the opening angle of the ridge vents manually.

The ventilation openings of the greenhouse with alternate ridge vent design were designed as 8 alternatively arranged vents, each with the size of 1.9 by $1.1 \mathrm{~m}$. In the continuous ridge vent design, a $1.1 \mathrm{~m}$ wide ridge vent was installed along the full length of the ridge at the leeward side. So that the total area of roof opening of the ridge vents in both designs were the same. The insect screen covering side vents were placed in the side walls from gutter height down to $0.5 \mathrm{~m}$ from the ground. Roofs of the A-frame greenhouses were extended beyond the gutter for the convenience of discharging rain water (Figure 1). All the greenhouses were naturally ventilated even though forced-air ventilation was possible in greenhouse (b) and (c).

During this study, four tests were conducted. All tests were done without crops in the greenhouses as replicated trials. For each test, data of three days were summarized to form a single replicate and treatments were replicated three times, following Kamaruddin et al. (2002) and Weerakkody et al. (2004). First (during Test 1), the arch shaped roof was compared with the straight roof (A-frame) without roof (ridge) vents. During Test No. 2, the type of ridge vents were compared using three greenhouses having alternate (double sided), continuous (leeward) and no ridge vents, keeping the external environment as the control. During Test No. 3, the effect of orientation of the ridge opening (with respect to wind direction) was examined, adjusting the ridge vents of the alternate ridge vent greenhouse to form three treatments namely, leeward vent orientation, windward vent orientation and alternate orientation, keeping the same opening area, during a time sequence. During test No. 04, the effect of opening area of the ridge opening was tested using four treatments, created by adjusting the opening area of alternate ridge vents during a time sequence. Full opening, opening up to $2 / 3$, opening up to $1 / 3$, and fully closed were the four treatments. The percentages ridge opening area (with respect to floor area) of the treatments were 14, 9.3, 4.7 and 0 , respectively while aspect ratios of the ridge vents (height/width of the opening area) were $0.53,0.36,0.27$ and 0 , respectively.

Using a PC-based automatic data acquisition system, internal and external temperature, RH, solar radiation and outside wind speed were recorded at 15 second intervals. The internal sensors were first caliberated and then mounted underneath light and heat insulated cups (to minimize errors due to direct effects of radiation) in the middle of the greenhouse underneath the ridgeline at gutter height. Semi-conductor temperature sensors (NATIONAL SEMICONDUCTOR; model LM 35) and RH sensors (TDK; model 7234648) were mounted at three locations in each greenhouse. External environmental parameters including wind speed (CAMPBELL SCIENTIFIC; Anemometer Model EE-460 ) were collected by mounting sensors $8 \mathrm{~m}$ away from the greenhouses, facing the windward, and at the same height and with the same degree of protection and insulation with respect to internal environmental sensors. Sensors were connected to a PC-based data acquisition and control system. Using the data collected, hourly and daily means and standard deviations were calculated. The temperature and humidity measurements taken between 9:00 and 17:00 $\mathrm{h}$ were utilized for testing the 
(b)

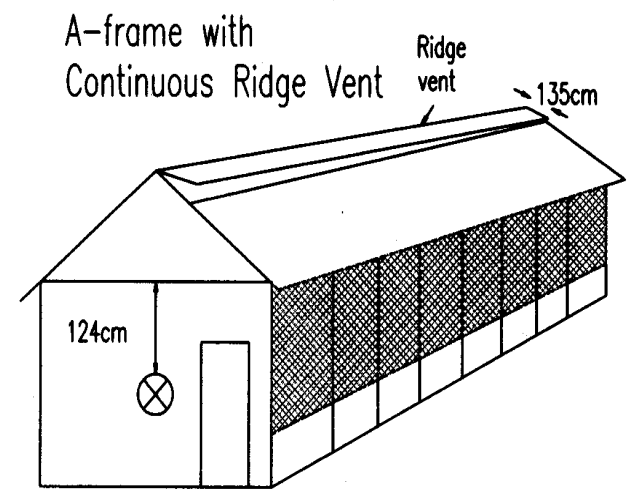

(a) A-frame with

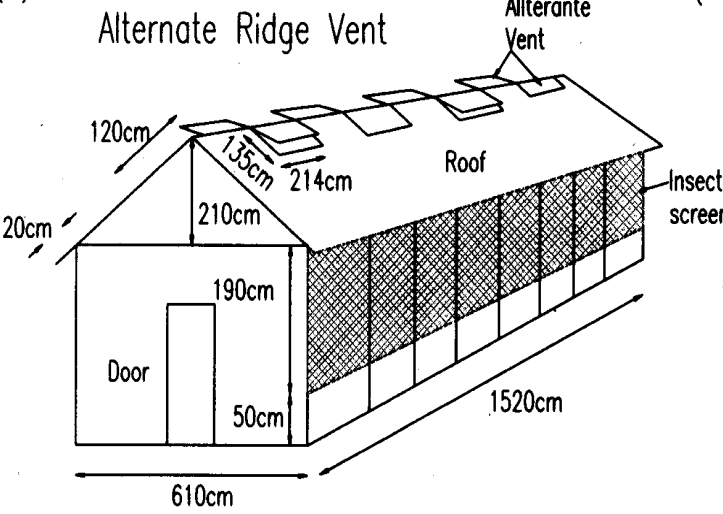

(d) Arch frame (without ridge vent)

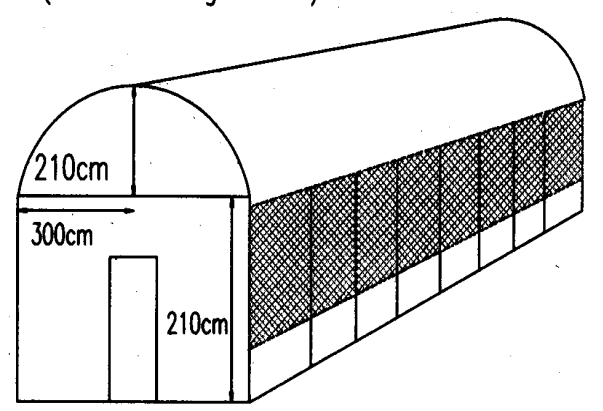

(C) A-frame without Ridge Vent

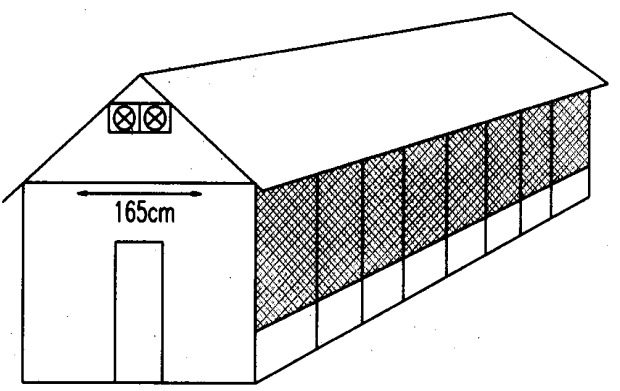

Figure 1: Roof and vent dimensions of the different greenhouse designs (drawing not to scale). Note: The unmarked dimensions in all A-frame houses are similar to greenhouse (a).

treatment effect as it was the critical period for greenhouse temperature control (cooling) through ventilation. Wind speed data were grouped into four levels based on the wind velocity.

The temperature and relative humidity data were statistically analyzed through ANOVA procedure of SAS (SAS, 1999) at 30 minute intervals at the probability level of $\mathrm{p}=$ 0.05. However, for the convenience of comparing treatments at a varying outside conditions, the data is presented in the form of internal and external differences in temperature and relative humidity. For testing the effect of wind on the ventilation based temperature and relative humidity changes in the greenhouse, data were summarized with respect to distinct regimes of wind speed and analyzed similarly (Herath, 2002; Weerakkody et al., 2007).

\section{RESULTS}

\section{The external environment}

During the experimental period, the mid day relative humidity in the environment varied within $40-50 \%$ while the maximum temperature ranged within $30.5-36{ }^{\circ} \mathrm{C}$ (Figure 2). The minimum (night) temperatures ranged within $18.6-22.4{ }^{\circ} \mathrm{C}$ while the mean night time RH was much higher (72.4-75.4\%). 


\section{Roof shape}

The results of Test 1 indicated that greenhouse temperature difference from the outside environment during the daytime (between 09:00 and 17:00 h) was significantly lower $(\mathrm{p}=0.05)$ for the A-frame greenhouse $\left(3.4{ }^{\circ} \mathrm{C}\right)$ than the curved roof greenhouse $(5.1$

${ }^{\circ} \mathrm{C}$ ) (Figure 3). Therefore, the slanted roof of an A-frame greenhouse was found to perform better than the curved roof of conventional greenhouses in Sri Lanka for effective greenhouse cooling through natural ventilation. Since the volume of air in both greenhouse types was the same, the difference must be solely due to the roof shape and associated differences in aero-dynamics and number of air-exchanges. However, the mean internal and external difference in relative humidity $(2.8-4.2 \%)$ was not statistically significantly different $(\mathrm{p}=0.05)$ between the different roof shapes.

\section{Ridge ventilation}

As shown in Figure 4a, the A-frame greenhouse without ridge vents (control) had the greatest temperature rise during the daytime during Test 2 . The mean difference from the outside temperature was $7.1 \pm 1{ }^{\circ} \mathrm{C}$. Both type of ridge vents contributed to reduce the internal temperature by $3.5 \pm 0.3{ }^{\circ} \mathrm{C}$. The mean temperature difference between the treatment 1 (alternate ridge vent) $(32.1 \pm 0.9$ ${ }^{\circ} \mathrm{C}$ ) and treatment 2 (continuous ridge vent) $\left(32.3 \pm 1.1{ }^{\circ} \mathrm{C}\right)$ was not statistically significantly different $(\mathrm{p}=0.05)$. However, the maximum greenhouse temperature rose above $35{ }^{\circ} \mathrm{C}$, a temperature undesirable for plant growth (Bailey, 2004). The mean wind speed during the experiment was less than $1.5-2 \mathrm{~m} \mathrm{~s}^{-1}$, the minimum wind speed required for effective wind driven ventilation in greenhouses (Bot, 1983; Kacira et al., 2004).

The relative humidity $(\mathrm{RH})$ during the daytime was generally lower inside the greenhouses compared to outside. The difference was significantly lower for treatments $1(5.0 \pm 1 \%)$ and $2(5.7 \pm 1.2 \%)$ $(\mathrm{p}=0.05)$, which had ridge vents, compared to treatment 3 , without ridge vents $(8.6 \pm 2.6 \%)$. Hence, both type of ridge vents contributed to reduce the RH difference only by $2.9 \pm 2.0 \%$. However, the type of ridge vent appeared to be insignificant $(\mathrm{p}=0.05)$ for the ventilation based relative humidity increase (Figure $4 b$ ). Hence, this result points to the positive effects of using ridge vents for controlling the greenhouse environment.

\section{Orientation of ridge vent}

According to the results of Test 3, there was no significant difference in internal temperature $(\mathrm{p}=0.05)$ among different orientations of the ridge vent (with respect to wind direction), indicating low effectiveness of the adjustable ridge vents. The effect of orientation of the ridge vent was also not significant on the ventilation based relative humidity change (Table 1).

Furthermore, the non-significant effect of ridge orientation can also be attributed to the confounding effect of wind speed since mean wind speeds that prevailed during treatments 1, 2 and 3 were, in the descending order, $0.37 \pm 0.11 \mathrm{~m} \mathrm{~s}^{-1}, 0.28 \pm 0.01 \mathrm{~m} \mathrm{~s}^{-1}$ and $0.18 \pm 0.63 \mathrm{~m} \mathrm{~s}^{-1}$, respectively. Adjusted data with respect to equal wind regimes (not presented) showed a greater influence of leeward and alternate ridge vent orientations on temperature control, compared to the windward orientation.

\section{Opening area/aspect ratio of ridge vents}

The size of the opening area of the ridge vent ranging between $4.7 \%$ and $14 \%$ of floor area appeared not to impact greenhouse temperature and humidity during the daytime (Table 1). Based on this result, it will be possible to reduce the opening area of the ridge vents from $14 \%$ to $4.7 \%$ of the floor area or the aspect ratio from 0.53 to 0.27 (keeping the same opening area) without affecting the ventilation rate. 


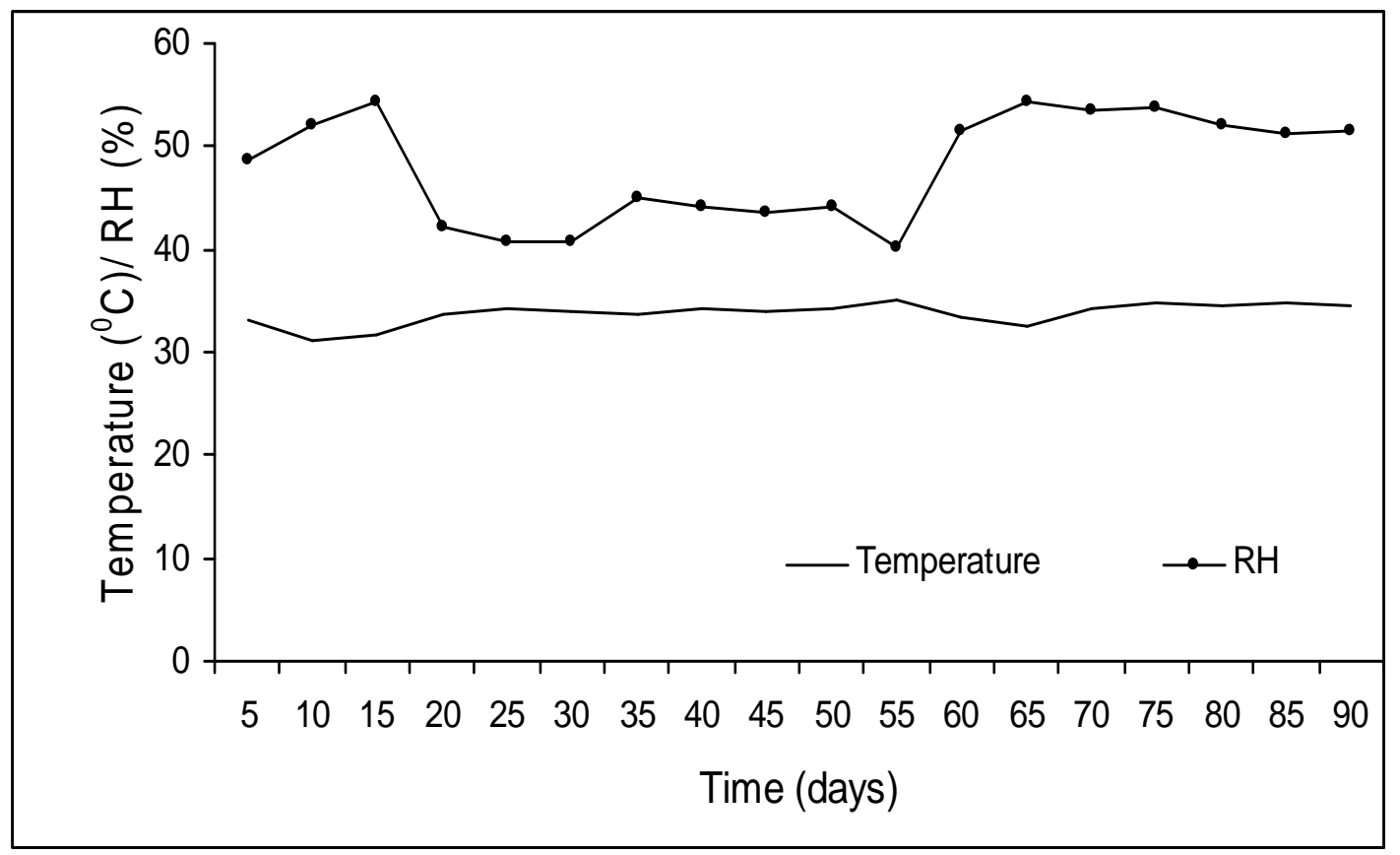

Figure 2: Variation of average outside environmental conditions during the daytime (9:00 - 17:00 h) during the experimental period.

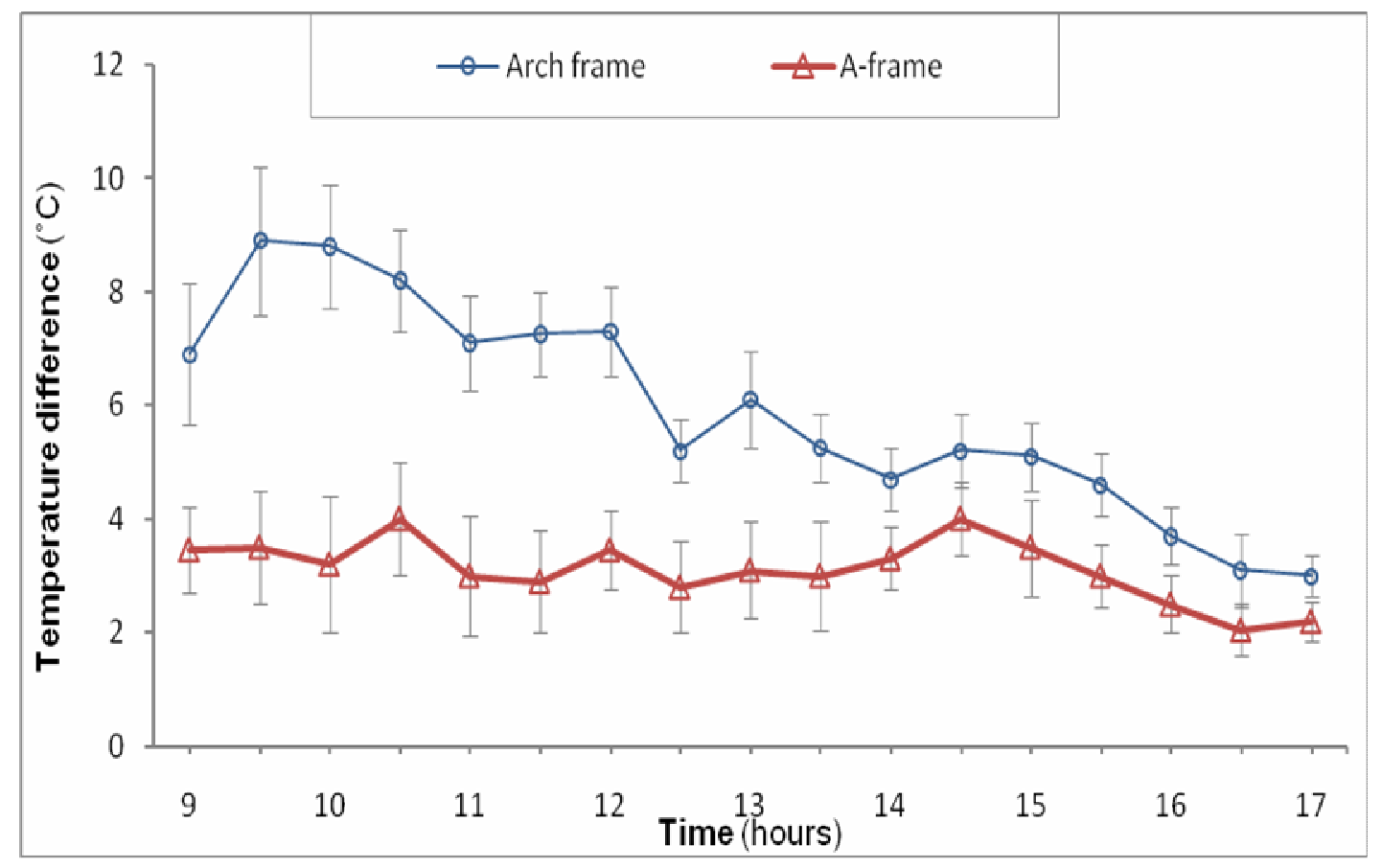

Figure 3: Variation in temperature difference for the different types of greenhouses during the daytime (hourly means of 9 days). Values are Means \pm SD. 

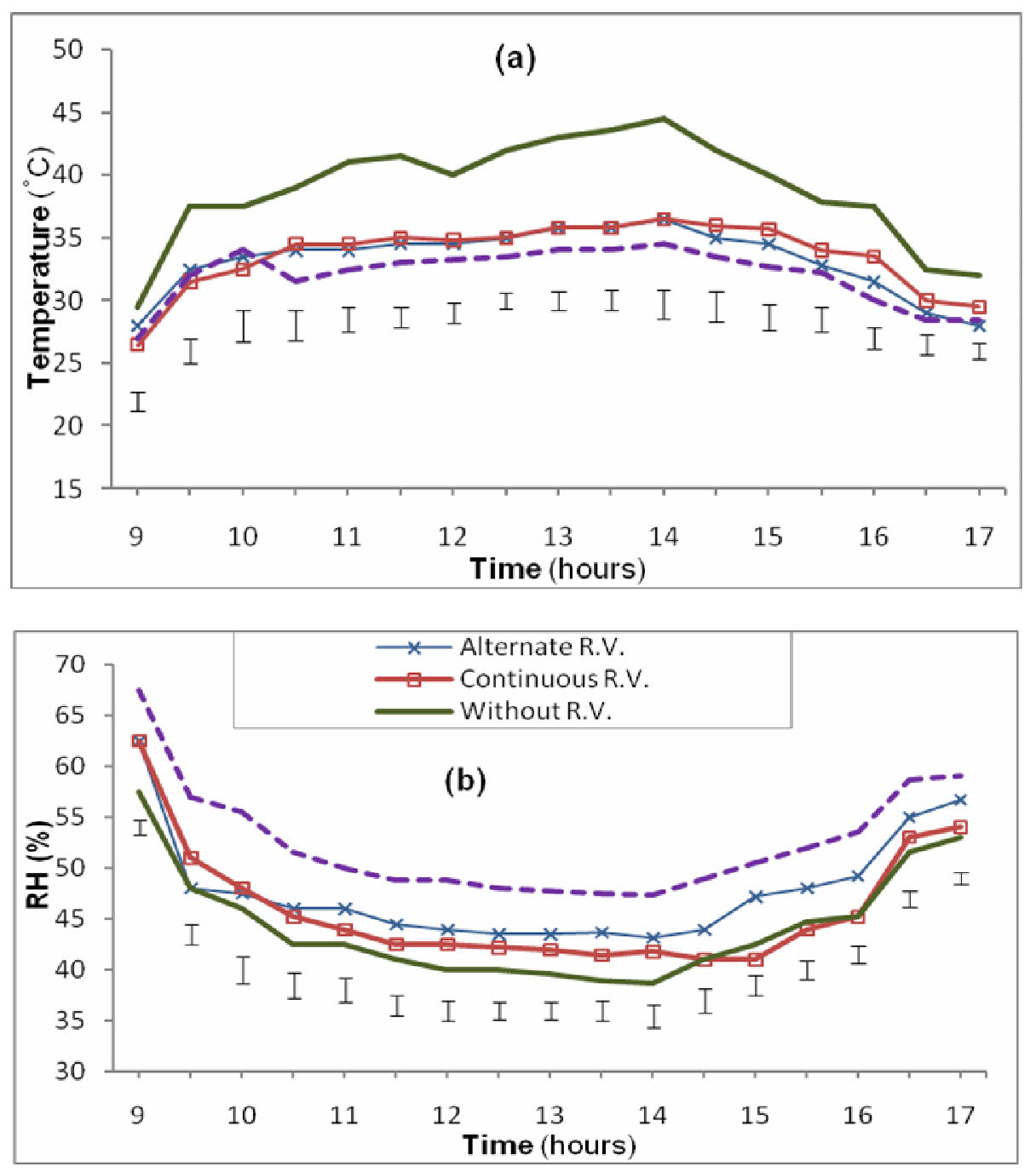

Figure 4: Effect of type of ridge vent on greenhouse temperature (a), and relative humidity (b) during the daytime (hourly means of 9 days).

Table 1: Ventilation based temperature and humidity differences between greenhouse and outside at different ridge orientations and opening areas using the alternate ridge vent design.

\begin{tabular}{lcc|ccc}
\hline $\begin{array}{l}\text { Ridge - } \\
\text { Orientation }\end{array}$ & $\begin{array}{c}\text { Temperature } \\
\left({ }^{\circ} \mathbf{C}\right)\end{array}$ & $\begin{array}{c}\text { RH } \\
(\boldsymbol{\%})\end{array}$ & $\begin{array}{c}\text { Opening } \\
\text { area }\end{array}$ & $\begin{array}{c}\text { Temperature } \\
\left({ }^{\circ} \mathbf{C}\right)\end{array}$ & $\begin{array}{c}\text { RH } \\
(\boldsymbol{\%})\end{array}$ \\
\hline Windward & $4 \pm 0.46^{\mathrm{a}}$ & $5.2 \pm 0.58^{\mathrm{a}}$ & $14 \%$ & $3.7 \pm 0.37^{\mathrm{b}}$ & $5.2 \pm 1.5^{\mathrm{b}}$ \\
Leeward & $4.3 \pm 0.45^{\mathrm{a}}$ & $4.3 \pm 0.65^{\mathrm{a}}$ & $9.30 \%$ & $3.2 \pm 0.8^{\mathrm{b}}$ & $4.3 \pm 0.8^{\mathrm{b}}$ \\
Alternate & $3.5 \pm 0.52^{\mathrm{a}}$ & $3.6 \pm 0.43^{\mathrm{a}}$ & $4.70 \%$ & $2.9 \pm 1.2^{\mathrm{b}}$ & $5.2 \pm 1.1^{\mathrm{b}}$ \\
& & & $0 \%$ (closed) & $7.3 \pm 2.25^{\mathrm{a}}$ & $7.7 \pm 1.78^{\mathrm{a}}$ \\
\hline
\end{tabular}

Tabulated daytime averages in temperature and RH differences are mean \pm SD of 9 determinations.

Letters in superscripts denote the treatment differences at $\mathrm{p}=0.05$. 


\section{Wind effect}

The interactions of wind speeds (up to $0.5 \mathrm{~m} \mathrm{~s}^{-1}$ ) with the orientation or the opening area (aspect ratio) of the ridge vents were not significant $(p=0.05)$ in terms of greenhouse temperature and RH. Although these were statistically significant for the type of ridge vent, there was an inconsistency in correlations (positive/negative). However, the difference between internal and external temperature and $\mathrm{RH}$ were negatively correlated with the wind speeds only up to 0.5 $\mathrm{m} \mathrm{s}^{-1}$ (irrespective of the ridge vent treatments). According to this relationship, a very low wind of $0.25 \mathrm{~m} \mathrm{~s}^{-1}$ was adequate to reduce the temperature as well as the relative humidity (Figure 5). Typical wind pattern in the experimental site on a selected day (Figure 6) reveals the inconsistency of wind speed where the cumulative time of scattered high winds (higher than $2 \mathrm{~m} \mathrm{~s}^{-1}$ ) was about 50 minutes.

\section{DISCUSSION}

With natural ventilation through side net cover, slanted roof design of A-frame greenhouse could maintain a lower mean temperature during daytime compared to conventional curved roof greenhouses in Sri Lanka. Since the air in both greenhouse types was the same, the difference must be solely due to roof shape and associated differences in aero-dynamics. According to earlier work, under low wind speeds where natural buoyancy dominates, a combination of roof and side vents were required to maintain an effective rate of air exchange (Kittas et al., 1997; Fatnassi et al., 2002; Kalsoulas et al., 2006). This fact was supported by the lowest temperature difference found for the greenhouse with continuous ridge vents. Therefore, testing the comparative performances of the two roof shapes on a greenhouse design having a combination of roof and side vents under different levels of wind speeds appeared to be another consideration before concluding their comparative performances. Furthermore, the possible temperature variation along the vertical plane in the greenhouse has been reported as $5{ }^{\circ} \mathrm{C}$ for A-frame greenhouses under similar conditions (Soni et al., 2005), and that might vary with the roof shape. Therefore, the temperature difference between two greenhouse types at other height levels might be slightly variable from the difference at the canopy height (the location of the temperature sensors).

Incorporation of ridge vents into the natural ventilation design in single span Aframe greenhouses, having screen-covered side vents, improved the ventilation based greenhouse temperature and $\mathrm{RH}$ during the daytime. This is in agreement with Kacira et al. (1998) who identified the necessity of having a roof vent to maintain the natural airflow pattern. Montero and Anton (2000) and Kalsoulas et al. (2006) have also shown a greater greenhouse ventilation capacity when combine ridge vents with side vents under tropical conditions. Hence, the advantages of adjustable ridge vents resolves over the conventional fixed top vents include higher cooling effect and reduced access for pests, reduced humidity and rain splash in tropical greenhouses in Sri Lanka. In addition, the possibility of changing the orientation of the ridge vent is highly applicable for the situations with seasonal changes in wind direction.

Comparatively, high rate of ventilation based greenhouse cooling expected in both directional roof vents (Bailey et al., 2004) was not found in alternate ridge vent design, compared to leeward ridge vent design. The reason for this result and the high mean and maximum greenhouse temperatures prevailed 

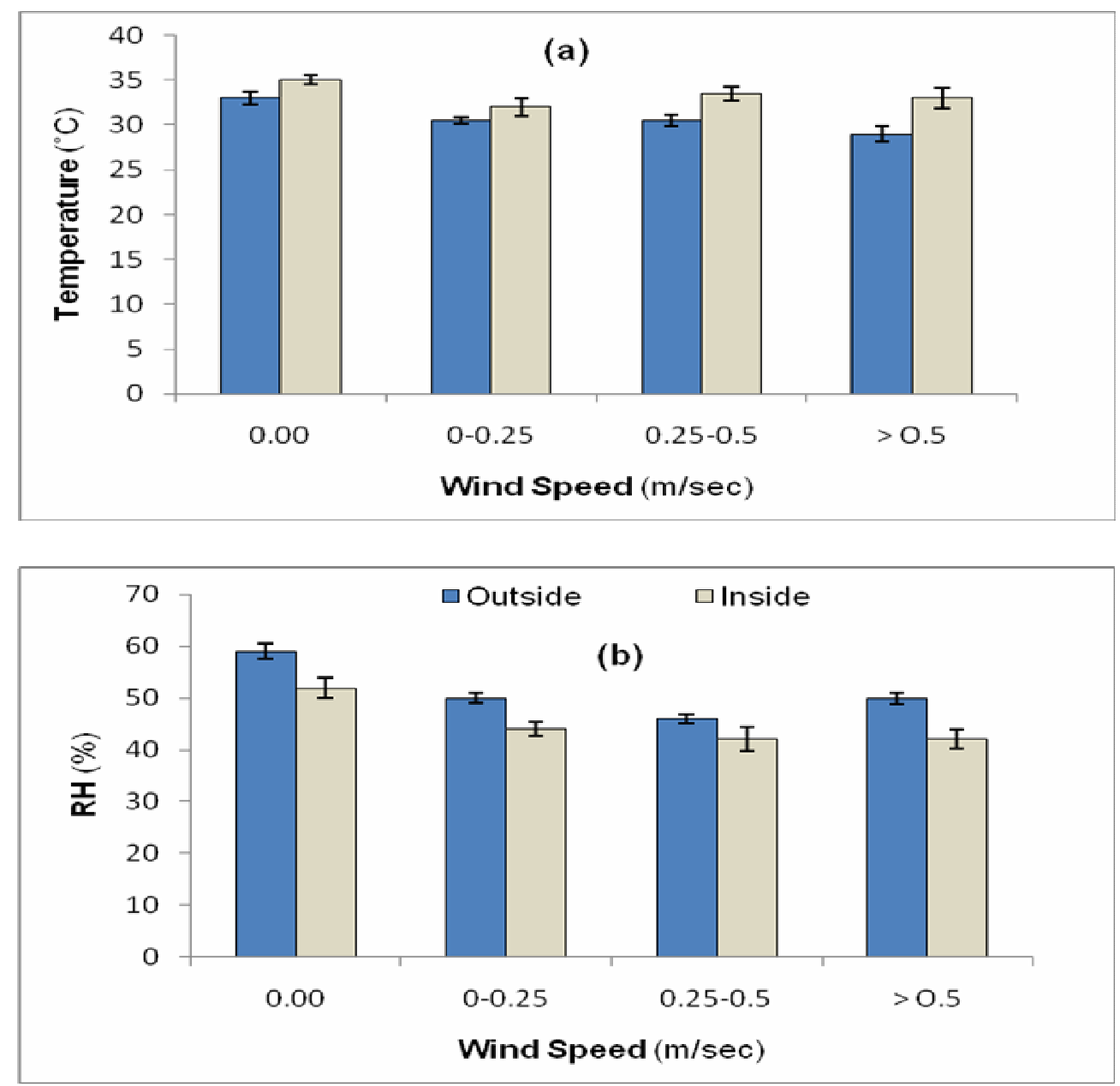

Figure 5: Influence of wind speed on greenhouse (inside) and environment (outside) conditions (means of $10-30$ entries). Vertical bars indicate the LSD at $\mathrm{p}=0.05$.

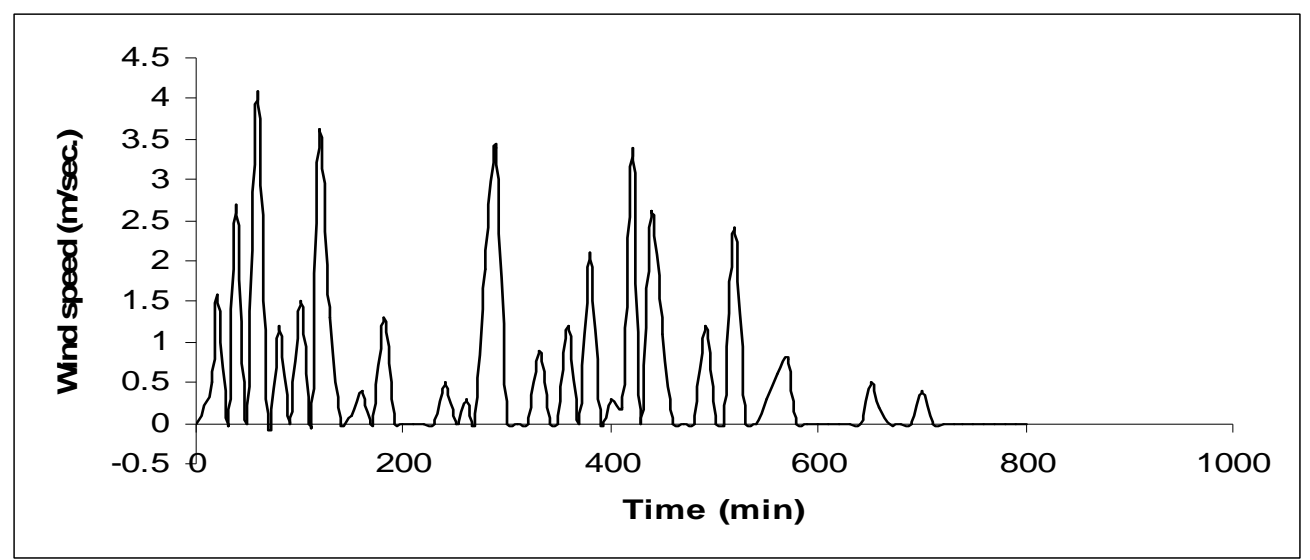

Figure 6: Typical wind pattern in the experimental site (in a selected day). Mean wind speed: $0.533 \mathrm{~m} \mathrm{~s}^{-1}$. 
during the experiment could be due to low mean wind speeds $\left(0.5 \mathrm{~m} \mathrm{~s}^{-1}\right.$, Figure 5) and inconsistent direction of winds during intermonsoon (data not presented). As specified by Kittas et al. (1997) and Fatnassi et al. (2002), the chimney effect (buoyancy flow) that dominates over the wind effect at low wind speeds, appears to be not adequate for ventilation based temperature reduction under hot weather. Furthermore, insufficient air exchange through insect screens (Fatnassi et al., 2002; Kalsoulas et al., 2006) could also have contributed to significantly higher temperatures in the greenhouse without roof vents, particularly under low wind speeds. Hence, further improvements would be possible by replacing insect screens with a larger mesh size or by temporary opening the side vents during the peak hot hours of the day.

Non-significant difference in greenhouse temperature between two orientations of the roof vent agrees with the lack of significant differences in temperature and $\mathrm{RH}$ between alternate (both sides) and continuous (leeward) ridge vents as described earlier in the paper. However, it is contradictory with the reports on similar experiments in multi span structures without side vents (Bailey et al., 2004), where windward vents or combination of windward and leeward vents were $30 \%$ more effective than leeward vents alone. It also does not agree with the reports on the superiority of a combination of windward side vents and leeward ridge vents over the other combinations for a rapid exchange of air in multi span structures (Kacira et al., 1998; Short, 2002). Based on the comments about the determining factors for horizontal airflow in greenhouses (Kittas et al., 1997; Detour and Wang, 1999; Kacira et al., 2004), this could be due to a drastic reduction in the wind driven component of air exchange under low wind speeds (less than $2 \mathrm{~m} \mathrm{~s}^{-1}$ ) and the inconsistent direction of prevailing winds during the experiment. The domination of the stack effect (buoyancy flow) over the wind effect under low wind speeds (as described above) also supports this observation.

As specified by Montero and Anton (2000) for successful greenhouse ventilation, a combination of ridge vent area of $10 \%$ and side vent area of $16 \%$ is required. Therefore the insignificance of the ridge vent orientation could also be due to the airflow restriction caused by the insect screens located in the side vents. Although the estimated side vent area of the screens was $30 \%$ of the floor area (that was determined from the assumption of a $50 \%$ air flow reduction as described by Montero et al. (1997)), it might not be adequate under low wind speeds and variable wind directions. The need to double the side vent area when wind direction changes from perpendicular to parallel in twin span curvedroof greenhouses (Vasiliou et al., 2000) supports this observation. Reports by Baudoin and von Zabeltitz (2002) and Fatnassi et al. (2002) on airflow restrictions caused by insect screens also support this. Therefore, it is worthwhile to test the actual ventilation capacity of the insect screen using advanced research techniques such as "tracer gas technology" (Lee et al., 2000) or "CFD modeling" (Baptista et al., 1999).

Further increase in the opening area of the roof vent beyond $4.7 \%$ (of the floor area) was ineffective on the ventilation based internal temperature control in A-frame greenhouses. Therefore, this finding enables greenhouse manager to reduce the risk of entering pests and rain splash through the ventilators by keeping a very small opening angle or aspect ratio of the ridge (roof) vent. This result agrees with the observations regarding the ineffectiveness of the opening angle of the ridge vents on ventilation rates in 
multi span structures without side vents (Bailey et al., 2004) but is contradictory to the results of earlier studies on multi-span structures with both side and roof vents where the area of the ridge vent or the aspect ratio is positively correlated with the ventilation rate (Kacira et al., 1998; Bailey, 2000; Short and Lee, 2002). By assuming the airflow pattern of multi-span structures is similar to single span structures within the same greenhouse type, above mentioned affinities logically indicate that the screen covered side nets have not played a effective role in ventilation based internal temperature control, confirming the earlier comments on the same.

Wind speed has been identified by many researchers as one of the major determinants of the rate of air circulation in greenhouses under diverse conditions (Kacira et al., 1998; Bailey, 2000; Short, 2002). However, due to highly variable and low mean wind speeds during the experiment, the effect of wind speed could only be determined only when "no wind" $\left(0 \mathrm{~m} \mathrm{~s}^{-1}\right)$ changed to very low wind speeds $\left(<0.25 \mathrm{~m} \mathrm{~s}^{-1}\right)$. So it appears that the impact of the wind component is not effective at higher wind speeds, speculating the barrier effect of the screened side vents. This may also be due to low upper margin (maximum) in the average wind speeds, low response time of the temperature and humidity to changes in wind speed, and less than desirable technical capability in the determination of wind speed.

Finally, it can be concluded that the Aframe (slanted roof) greenhouse design performed better compared to the curved roof design with respect to natural ventilation based temperature reduction (cooling) in single-span greenhouses under tropical conditions. Further improvements of the same with a ridge (roof) vent, having a minimum opening area of $4.7 \%$ (and an aspect ratio of 0.27) helped reducing internal temperature and relative humidity (RH) furthermore during daytime. Alternate double sided ridge orientation with its advantages of less operational needs and applicability under variable wind directions appeared to be more appropriate in this regard. The influence of the orientation and opening area (increasing aspect ratio) of the ridge vent were insignificant under slow winds prevailed and with the use of less efficient side vents. The influence of the latter was further assured by the ineffectiveness of the faster winds beyond $0.25 \mathrm{~m} \mathrm{~s}^{-1}$.

\section{ACKNOWLEDGEMENTS}

The authors wish to acknowledge the sponsorship of the National Research Council of Sri Lanka.

\section{REFERENCES}

Bailey BJ. 2000. Constraints, limitations and achievements in greenhouses natural ventilation. Acta Hort., 534: 21-30.

Bailey BJ. 2004. Natural and mechanical greenhouse climate control. Acta Hort. (ISHS), 710: 43-54.

Bailey BJ, Robertson AP, Lockwood AG. 2004. The influence of wind direction on greenhouse ventilation. Acta Hort., 633: 197-203.

Baptista FJ, Bailey BJ, Randall JM, Menses JF. 1999. Greenhouse ventilation rate: theory and measurement with tracer gas techniques. J. Agri. Eng. Res., 72: 363374.

Baudoin WO, Zabeltitz CHR. 2002. Greenhouse constructions for small-scale farmers in tropical regions. Acta Hort., 578:

Bot G. 1983. Greenhouse Climate: from physical process to a dynamic model. $\mathrm{PhD}$ dissertation, Wageningen Agricultural University, Wageningen (The Netherlands), p. 240. 
Central Bank. 2006. Central Bank Report, Central Bank of Sri Lanka, Colombo (Sri Lanka).

Deltour J, Wang S. 1999. Ventilation induced interior air movement in large-scale venlo type greenhouses. Acta Hort., 491: 119-124.

Fatnassi H, Boulard T, Bouirden L, Sappe G. 2002. Ventilation performances of a large Canarian type greenhouse equipped with insect-proof nets. Acta Hort., 578: 79-80.

Hanan JJ. 1998. Greenhouses: Advanced Technology for Protected Culture. CRC Press: New York.

Herath HMMS. 2003. Design and development of a data acquisition and control system for greenhouses. BSc dissertation, University of Peradeniya, Peradeniya (Sri Lanka), p. 125.

Jenson MH, Malter JA. 1995. Protected Agriculture; a Global Review (253). World Bank Publ.: Washington.

Kacira M, Short TH, Stowell RR. 1998. A CFD evaluation of naturally ventilated, multi-span, saw-tooth greenhouses. American Soc. Agric. Eng., 41(3): 833836.

Kacira M, Sase S, Okushima L. 2004. Optimization of vent configuration by evaluating greenhouse and plant canopy ventilation rates under wind induced ventilation. Trans. ASAE, 47(6): 20592067.

Kalsoulas N, Bartzanas T, Boulard T, Mermier M, Kittas C. 2006. Effect of vent opening and insect screens on greenhouse ventilation. Biosys. Eng., 93(4): 427-436.

Kamaruddin R, Bailey BJ, Montero IJ. 2002. A naturally ventilated greenhouse for temperate vegetable production in the tropics. Acta Hort., 578: 97-103.
Kittas C, Boulard T, Papadakis G. 1997. Greenhouse ventilation rates through combined roof and side openings: An experimental study. Acta Hort., 443: 3138.

Lee IB, Short TH, Sase S, Lee SK. 2000. Evaluation of computational fluid dynamics for analysis of aerodynamics in naturally ventilated multi-span greenhouse. Agri. Biosys. Eng., 1(2): 7380.

Montero JI, Munoz P, Anton A. 1997. Discharge coefficients of greenhouse windows with insect-proof screens. Acta Hort., 443: 71-78.

Montero JI, Anton A. 2000. Buoyancy driven ventilation in tropical greenhouses, Acta Hort., 534: 41-58.

Nelson PV. 1998. Greenhouse Operation and Management. Prentice Hall: New Jersey.

Niranen F, Gunasena HPM, Sakalasooriya MB. 2005. Survey on controlled environmental agriculture in Sri Lanka. Council for Agricultural Research Policy (CARP), 280/7, Wijerama mawatha, Colombo.

SAS. 1999. SAS/STAT Users Guide (Release 6.05). SAS Institute Inc. Carry N.C.

Short TH. 2002. Natural Ventilation: New Innovation Research in Aero Dynamics, The Dept. of Food, Agric. and Biol. Eng., Ohio Univ., Ohio.

Short TH, Lee IB. 2002. Two dimensional numerical simulations for natural ventilation in multi span greenhouses. Transactions of the ASAE, 43(3): 745753.

Soni P, Salokhe VM, Tanau HJ. 2005. Effect of screen mesh size on vertical temperature distribution in naturally ventilated tropical greenhouses. Biosys. Eng., 92(4) 469-482. 
Teitel M, Barak M, Zhao Y. 2006. Ventilation of a greenhouse with continuous roof and side vents. Acta Hort., 719: 41-47.

Vassiliou NN, Martzopoulos GG, NikitaMartzopoulou C. 2000. Determination of natural ventilation rate in a double span arch type greenhouse. Acta Hort., 534: 171-180.

Weerakkody WAP, Guneratne LHP, Peiris BCN. 2002. Implications and prospects of protected culture as a novel technology to foster horticulture in Sri Lanka. P.405 In Abstracts of the $26^{\text {th }}$ Int. Hort. Cong. (IHC), Toronto, Canada.

Weerakkody WAP, Amarathunga KSP, Kumara PASK. 2007. Applicability of forced- air and ridge ventilation for cooling of side net covered tropical greenhouses. Acta Hort. (ISHS), 710: 185-190. 